\title{
Alexander Hamilton on Slavery
}

\author{
Michael D. Chan
}

This article seeks to refute the prevailing scholarly view that Hamilton, like the Founders generally, lacked a deep concern about slavery. The first part examines Hamilton's political principles and shows that they were not Hobbesian but consistent with the views of more traditional natural law theorists. Accordingly, Hamilton understood that the natural rights of man imposed a corresponding duty to end slavery. The second part examines Hamilton's endorsement of a compensated emancipation, his opinions of the Constitution, his conduct of American foreign policy, his involvement in the state abolition societies, and his economic policies to demonstrate that ending slavery was in fact one of his abiding concerns.

When people read the opening of Abraham Lincoln's Gettysburg Address, the man who most naturally comes to mind as the one who brought forth "a new nation, conceived in Liberty, and dedicated to the proposition that all men are created equal" is undoubtedly Thomas Jefferson; after all, Jefferson penned the lines of the Declaration of Independence. Yet in Lincoln's view, Jefferson was not the best oracle to consult for dealing with slavery under the Constitution. ${ }^{1}$ Rather, Lincoln harkened to the opinions of the "thirty-nine fathers who framed the original Constitution," and among those thirty-nine men, Lincoln pointed out that the "most noted antislavery men of those times" included "Dr. Franklin, Alexander Hamilton and Gouvernor Morris."

Despite Lincoln's opinion, contemporary scholars tend to ignore Hamilton's strong opposition to slavery. Some of the more sympathetic ones such as Forrest McDonald and Thomas West note Hamilton's opposition, but the subject is usually treated in a perfunctory manner. ${ }^{3}$ Instead, the lingering influence of Charles Beard's

1. Jefferson's doctrine of nullification and his opposition to the North's attempt to ban slavery from Missouri as a condition of entry into the Union (which he regarded as a Northern Federalist plot aimed at "consolidation") did not comport with Lincoln's own views.

2. Abraham Lincoln, "Address at Cooper Institute," 27 February 1860 , in Abraham Lincoln: Speeches and Writings, 1859-1865, ed. Donald E. Fhrenbacher (New York: The Library of America, 1989), p. 117 (emphasis added).

3. Forrest McDonald, Alexander Hamilton: A Biography (New York: W. W. Norton \& Co., 1979), pp. 121, 212-13; Thomas G. West, Vindicating the Founders: Race, Sex, Class and Justice in the Origins of America (New York: Rowman and Littlefield Publishers, 1997), pp. 5, 8, 12; Paul Finkelman, Slavery and the Founders, 2nd ed. (Armonk, NY: M. E. Sharpe, Inc., 2001), pp. 105-128; Stanley Elkins and Eric McKitrick, The Age of Federalism (New York: Oxford University Press, 1993), p. 99. 
economic determinism, both the liberal and "neoclassical" schools of interpretation of the American Founding, and the DemocraticRepublican Party propaganda of the era have conspired to leave us with a characterization of Hamilton as a nominally republican, but substantially anti-egalitarian defender of the commercial classes who was as token in his opposition to slavery as were his opponents. In his biography of Hamilton, Jacob Cooke concisely expresses the view held by many: "In his lack of deep concern about either slavery or its concomitant racism (prevalent in the North as well as the South), [Hamilton] joined the overwhelming majority of his countrymen, political foes and allies alike." ${ }^{4}$ Even Harry Jaffa-a scholar otherwise sympathetic to the Founding generation-concedes a certain amount of complacent indifference about slavery among the Founders, and traces it to the very principles of the Revolution: "it is also true that the widespread lack of concern over the moral challenge of Negro slavery to the doctrine of universal rights in the Declaration in the Revolutionary generation can be traced to the egoistic quality of these rights in their Lockean formulation. ... In truth, their principle included the Negroes in 'all men,' but the Negroes' rights did not impose corresponding duties upon the white masters."

Such an interpretation, however, does not do Hamilton justice, for he was fully aware that the American Revolution would ultimately be judged by whether it lived up to its own principles. To be sure, Hamilton devoted most of his enormous energy to the more immediate tasks of "nation-building," but this does not mean that he simply neglected the issue of slavery. As we shall see from his opinions on fundamental political and constitutional principles to his endorsement of a gradual emancipation to his conduct of American foreign policy to his personal involvement in the state abolition societies to his economic policies, Hamilton was steadfastly committed to the eventual abolition of slavery, and was certainly not so complacent as to leave his commitment to the mere hope that slavery was on a path to ultimate extinction.

4. Jacob Emest Cooke, Alexander Hamilton (New York: Charles Scriber's Sons, 1982), p. 45; "Neither Hamilton nor Jay boldly championed the cause [of abolition]." David Brion Davis, The Problem of Slavery in the Age of Revolution 1770-1823 (Ithaca: Cornell University Press, 1975), p. 172.

5. Harry V. Jaffa, Crisis of the House Divided (Chicago: University of Chicago Press, 1959), p. 324. See also Herbert J. Storing, "Slavery and the Moral Foundations of the American Republic," in Toward a More Perfect Union: The Writings of Herbert J. Storing, ed. Joseph M. Bessette (Washington D.C.: The AEI Press, 1995), pp. 142-44. 


\section{Hamilton on Morality and Slavery}

As the opening quotes from Jaffa and Cooke indicate, there is some question as to whether Founders such as Hamilton understood the doctrine of natural rights to include a corresponding duty to extend those rights to America's slaves. Historians generally follow Jefferson in framing the issue as a balance between self-preservation or property rights on the one side, and justice or the rights of slaves on other, with many arguing that the principles of the Revolution furnished no definitive guidance in favor of the rights of slaves. ${ }^{6}$ We must therefore establish Hamilton as a bona fide opponent of slavery who left no ambiguity as to how he interpreted America's fundamental principles. To that end, we recur mainly to Hamilton's writings in the years leading up to the American Revolution. Although these early writings had a distinctly polemic tone, his arguments nevertheless provide a full indictment of slavery irrespective of the particular context of the American Revolution.

In justifying his opposition to the "system of slavery" which he believed characterized British rule, ${ }^{7}$ Hamilton began his Full Vindication with a recurrence to first principles: "All men have one common original: they participate in one common nature, and consequently have one common right. No reason can be assigned why one man should exercise any power, or pre-eminence over his follow creatures more than another; unless they have voluntarily vested him with it." This most succinct formulation of Lockean doctrine requires some elaboration. According to Locke, men are naturally equal because they are members of the same species, and since nature does not demarcate the naturally superior and inferior among men as nature does between

6. Davis, Problem of Slavery, pp. 260-69; Finkelman, Slavery and the Founders, pp. 39-40; James L. Huston, Calculating the Value of the Union: Slavery, Property Rights, and the Economic Origins of the Civil War (Chapel Hill, NC: University of North Carolina Press, 2003), pp. 7-23; Michael Kammen, "The Rights of Property, and the Property in Rights': The Problematic Nature of 'Property' in the Political Thought of the Founders and the Early Republic," in Liberty, Property, and the Foundations of the American Constitution, ed. Ellen Frankel Paul and Howard Dickman (Albany, NY: State University of New York Press, 1989), pp. 8-11, 14; Forrest McDonald, Novus Ordo Seclorum: The Intellectual Origins of the Constitution (Lawrence, KS: University Press of Kansas, 1985), pp. 53-5.

7. Alexander Hamilton, "A Full Vindication," in The Papers of Alexander Hamilton, ed. Harold C. Syrett (New York: Columbia University Press, 1961), 1: 51. Hereafter cited as $P A H$, volume and page number.

8. Ibid. 
man and the lower animals, no man can be said to be naturally subordinate to another. Relations between men must therefore be based on consent. Moreover, if there is no natural subordination among men, then men cannot be said to be naturally in a state of government or civil society, but instead must be considered in a state of nature where they are naturally free and independent. Since men do not have any government in the state of nature, they are left to guide their actions by the laws of nature. The first principle of our nature is the desire for self-preservation because it is our strongest desire, and the sine qua non of all other things; accordingly, it is man's first natural right. But if one desires the end of self-preservation, then one must also have the means to that end. One must therefore have a perfect freedom to order one's actions as one sees fit in order to secure one's life. It must be a perfect freedom because to concede that an individual-even if he be eminently wise-may tell another how he should preserve his life would be to deny the fundamental equality of all men, and in any case, even if such a man were to exist, no man has as much interest in his own self-preservation as himself. Finally, one must also have sustenance to survive. One must also therefore have a right to acquire and possess property. This, in a nutshell, is the derivation of man's natural rights to life, liberty, and property. ${ }^{9}$

Applied to the issue of slavery, the equality of all men in certain natural rights means there cannot be any justification for one man enslaving or owning another. All men have a right to the fruit of their own, not someone else's labors. Thus slaves everywhere had the undeniable right to "appeal to heaven" and try to throw off their yokes. Of course, this was small consolation to America's slaves, since they hardly needed an elaborate theory of rights to try to free themselves from bondage by force. They might receive greater consolation if men were obligated to recognize natural rights in all human beings. But unfortunately, in Locke's state of nature there are rights, but no real duties, a result which stems from the overriding goal of self-preservation. ${ }^{10}$ In Locke's state of na-

9. John Locke, Two Treatises of Government, ed. Peter Laslett (New York: Cambridge University Press, 1988), II, I 4, 6-8, 17, 22-3, 25-7, pp. 269-88.

10. Jaffa, Crisis of the House Divided, pp. 323-27; Leo Strauss, Natural Right and History (Chicago: University of Chicago Press, 1953), pp. 202-51; C. B. MacPherson, The Political Theory of Possessive Individualism (New York: Oxford University Press, 1962), pp. 194-262. There are, of course, other interpretations of Locke, but the Hobbesian or bourgeois interpretation of both Locke and the principles of the Revolution dovetails with the allegation that many founders were more concerned about the rights of property (self-preservation) than the rights of slaves (justice). Davis (Problem of Slavery, pp. 268-9), for example, explicitly draws on C. B. Macpherson. Nevertheless, my interpretation of Hamilton is broadly consistent with the interpretations of Locke found in: Steven M. Dworetz, The Unvarnished 
ture, one ought "to preserve the rest of mankind," but only "when his own preservation comes not in competition." "ll Where Lockean doctrine does give some hope for slaves is if one considers slavery from the point of view of enlightened self-interest. He who does not enslave others increases his own security by not making enemies of his fellow men. The moral policy that results from this calculation is: he who would not be a slave ought not be a master. The corollary to this is that he who would be a master is potentially the master of all since one can reasonably suppose that he who would violate the rights of another will have no scruple in violating the rights of all if given the opportunity, or as Hamilton put it, one "cannot encroach upon another, without becoming a common enemy, and eventually endangering the safety and happiness of all." 12

But if the universal respect of men's rights is grounded merely in enlightened self-interest, then was not Hamilton guilty of lacking any true moral concern about slavery? For if the ultimate ground of men's natural rights is self-preservation, then the issue becomes simply a matter of weighing the benefits and costs of slavery. Given America's large slave population, it could easily be concluded that emancipation would be too costly. Hamilton would therefore seem to have been at a loss to provide any truly moral arguments against slavery. Yet Hamilton would have been at a loss only if Locke as interpreted here were the primary source of Hamilton's convictions. Certainly, many have suggested that Locke was "the deepest root for Jefferson's generation," and that the abolition of slavery was but "a long run requirement of the security of the rights of the selfregarding egotistical individual." 13 Nevertheless, what was apparently true of Jefferson was not necessarily true of the whole of his generation. While Hamilton read Locke and adopted many of Locke's positions, it is not altogether clear that Hamilton interpreted Locke as certain modern scholars have. We also know that he was influenced by other authors, and was not a doctrinaire disciple of any of them. Hamilton was too much the prudent statesman to allow himself to adhere too rigidly to the doctrines of "visionary projectors." If we are to understand Hamilton as he understood himself, we must more closely examine what he wrote.

Doctrine: Locke, Liberalism, and the American Revolution (Durham: Duke University Press, 1990); Michael P. Zuckert, Natural Rights and the New Republicanism (Princeton: Princeton University Press, 1994), Launching Liberalism (Lawrence, KS: University Press of Kansas, 2002).

11. Locke, Two Treatises of Government, II, ๆ 6, p. 271.

12. Hamilton, "A Full Vindication," $P A H, 1: 51$.

13. Jaffa, Crisis of the House Divided, p. 326. 
In the first instance, it is undoubtedly true that Hamilton rested part of his opposition to slavery on Lockean grounds. Hamilton fully echoed Locke when he wrote: "self-preservation is the first principle of our nature. When our lives and properties are at stake, it would be foolish and unnatural to refrain from such measure as might preserve them." 14 Nevertheless, Hamilton did not try, like Hobbes and Locke, to deduce all of his political reasoning from such a principle. It is more accurate to say that for Hamilton, selfpreservation may be man's first or initial principle, it may even be man's most consistent and reliable principle, but it is not man's highest principle. Higher than the principle of self-preservation is the principle of liberty: "No person, that has enjoyed the sweets of liberty, can be insensible of its infinite value, or can reflect on its reverse, without horror and detestation." 15 To men who recognize the true value of liberty, it induces in them "a certain enthusiasm" that "makes human nature rise above itself in acts of bravery and heroism." 16 Men are able to conquer their more base desire for selfpreservation and to put up a "manly and virtuous struggle,"17 sacrificing life, property, and sacred honor on the altar of liberty. In fact, according to Hamilton, "the principles of the revolution" positively "taught the inhabitants of this country to risk their lives and fortunes in asserting their liberty." 18 In these kinds of statements, Hamilton reverses Locke's formulation such that the desire for liberty, while initially coming to sight as a means to self-preservation, is in fact the more comprehensive appetite.

As a corollary, if liberty is a transcendent rather than an instrumental principle, then men become obliged not simply to assert their own liberty, but to respect the liberty of others. Indeed, the very manner in which Hamilton asserts the value of liberty suggests its universal and obligatory character, for to assert that "no person, that has enjoyed the sweets of liberty, can be insensible of its infinite value" means that all sensible people similarly situated would come to the same conclusion. And if we follow Hamilton's reliance on a kind of moral sense (perhaps derived from Hume), we need only add a bit of sympathy or fellow-feeling to come to the conclusion that a sensible man reflecting on slavery would react with "horror and detestation" not only to the possibility of his own slavery, but also to the slavery of others. In this light, slavery becomes

14. Hamilton, "A Full Vindication," $P A H, 1: 51$.

15. Ibid., p. 53 (emphasis added).

16. Hamilton, "The Farmer Refuted," $P A H, 1: 156$.

17. Hamilton, "A Full Vindication," $P A H, 1: 64$.

18. Hamilton, "Second Letter From Phocion," $P A H, 3: 545$ (emphasis added). 
not just an issue of the right of men to be free, but also the corresponding duty of men not to enslave others.

Yet Hamilton believed that liberty is grounded above all else in the natural rights of mankind. At the same time, he certainly recognized the problems posed by a Hobbesian understanding of natural rights, and explicitly rejected that understanding. According to Hamilton, Hobbes held that man in a state of nature is:

Perfectly free from all restraint of law and government. Moral obligation according to him, is derived from the introduction of civil society; and there is no virtue, but what is purely artificial, the mere contrivance of politicians, for the maintenance of social intercourse. But the reason he ran into this absurd and impious doctrine, was, that he disbelieved the existence of an intelligent superintending principle, who is the governor, and will be the final judge of the universe. ${ }^{19}$

In opposition to Hobbes, Hamilton contended that "good and wise" men like Grotius, Puffendorf, Locke, Montesquieu, and Blackstone averred that there is an "eternal and immutable law, which is, indispensably, obligatory upon all mankind, prior to any human institution whatsoever." ${ }^{20}$ That is to say, although man in the state of nature is perfectly free to order his actions without the consent of other men, his actions must nonetheless conform to the law of nature which, far from granting every man a right to everything in the name of his own self-preservation, proscribes violating the natural rights of others.

Moreover, if we turn to Hamilton's own interpretation of natural law, we find that it essentially accords with the more traditional understanding. According to Hamilton, the law of nature is discovered by reason which nature gave man not only to help him in "preserving" himself but also in "beatifying his existence." 21 To beatify one's existence is to go beyond the narrow dictates of selfpreservation to discover and pursue such things as are "consistent with [man's] duty and interest." 22 Furthermore, the promulgation of the natural law does not become an acute issue with Hamilton, because the basic natural law is more obvious than Locke suggests: "The sacred rights of mankind are not to be rummaged for, among old parchments, or musty records. They are written, as with a sun beam in the whole volume of human nature, by the hand of the divinity itself; and can never be erased or obscured by

19. Hamilton, "The Farmer Refuted," $P A H, 1: 87$.

20. Ibid.

21. Ibid (emphasis added).

22. Ibid., p. 88 (emphasis added). 
mortal power." ${ }^{23}$ In other words, Hamilton follows the Declaration (and even the Bible) in arguing that Nature endowed man with natural liberty which "is a gift of the beneficent Creator to the whole human race." 24 As a gift from god or nature to man, rather than a gift from man to man, man's natural liberty "is not a thing, in its own nature, precarious and dependent on human will and caprice; but is conformable to the constitution of man." 25 As man's liberty is an endowment from something higher than himself, he must respect the liberty inhering in all men as men (even those outside of the social compact). Consequently, we see that in Hamilton's state of nature, the law of nature denied all men "any moral power to deprive another of his life, limbs, property or liberty." 26 To be sure, this does not mean that there are no violations of right in the state of nature, but the existence of "moral power"27 in addition to physical power means that the respect for man's natural rights goes beyond a matter of rational calculation to secure one's own self-preservation.

Hamilton even went so far as to claim that man's natural rights "ought to be held sacred by every rational being." 28 Thus Hamilton, like other traditional natural law theorists, believed that man's rationality leads not to the denial but to the recognition of "sacred" restraints. ${ }^{29}$ And as a practical matter, these restraints must be regarded as not just natural but "sacred" for them to be fully respected by men. In fact, we can see this understanding of rights applied specifically to the issue of slavery by reviewing the preamble to the constitution of the New York Manumission Society which Hamilton signed as one its founding members:

The benevolent Creator and Father of Men having given to them all, an equal Right to Life, Liberty, and Property; no Sovereign Power, on Earth, can justly deprive them of either; but in Conformity to impartial Government and laws to which they have expressly or tacitly consented.

23. Ibid., p. 122.

24. Ibid., p. 104.

25. Ibid. (emphasis added).

26. Ibid., p. 122.

27. At the time of Hamilton's writing, "moral" causes or power referred to both ethics as well as the realm of man as distinct from nature (i.e., moral or "manmade" causes had not yet been drained of ethical content).

28. Ibid., p. 134 (emphasis added).

29. Notably, Hamilton uses "sacred" and natural interchangeably when referring to man's natural rights, a convention which Hobbes and Locke do not adopt. Compare Samuel Pufendorf, On the Duty of Man and Citizen According to Natural Law (New York: Cambridge University Press, 1991), bk. 1, chap. 3, ๆ 9-12, pp. 35-37. 
It is our Duty, therefore, both as free citizens and Christians, not only to regard, with compassion and Injustice done to those, among us, who are held as Slaves, but to endeavor by lawful ways and means, to enable them to Share, equally with us, in that civil and religious Liberty with which an indulgent Providence has blessed these States... ${ }^{30}$

Here we have a clear assertion of Lockean natural rights that includes a corresponding duty as free citizens to see that the full enjoyment of those rights are extended to slaves.

Yet, unlike the later Abolitionists, Hamilton did not regard the end of slavery as a moral obligation that simply trumped the rights of slaveholders. Indeed, given his extensive efforts to ensure that the government properly secured the rights of property, Hamilton, like the rest of the Founders, is charged with a certain moral cravenness in dealing with the problem of slavery. The issue then becomes not just one of discovering in Hamilton's thought a truly moral basis for opposing slavery, but also one of discovering how far he was willing to go in sacrificing the rights of humanity to the rights of property. Fortunately, we need not extrapolate his views on the matter because he directly addressed the issue. In a general discussion on the extent to which necessity may excuse otherwise immoral actions, Hamilton cited the case of "certain foedal [sic] rights which once oppressed all Europe and still oppress too great a part of it." These rights "made absolute slaves of a part of the community and rendered the condition of the greatest proportion of the remainder not much more eligible." $\mathrm{Al}$ though long-established, these rights were nevertheless "contrary to the Social order and to the permanent welfare of Society," and so were "justifiably abolished" and "may be abolished in all the remaining vestiges." ${ }^{31}$ Of course, if the feudal rights of the aristocracy in Europe enslaved a large portion of its population, then America was guilty of a similar injustice, since it too granted certain rights which made absolute slaves of a part of the community, namely, Negroes. We may therefore infer that the rights of American slaveholders might justifiably be sacrificed for the sake of the higher goods of life and liberty to which every human being is entitled as natural rights.

This does not mean, however, that the rights of property may be ignored in the pursuit of the permanent welfare of society. According to Hamilton:

30. New-York Historical Society, New York Manumission Society Records, 6:3-4, 9. Hereafter cited as NYMS Records, volume and page number. The overtly religious language probably reflects the significant presence of Quakers in the society.

31. Hamilton, "The Vindication No. III," $P A H, 11: 472$. 
Wherever indeed a right of property is infringed for the general good, if the nature of the case admits compensation, it ought to be made; but if compensation be impracticable, that impracticability ought not to be an obstacle to a clearly essential reform. ${ }^{32}$

It should be reiterated that Hamilton was not an Abolitionist. While believing in the injustice of slavery, Hamilton denied that the pursuit of abstract justice entitled citizens to overturn the ordinary rules of property. Slaves were long recognized as property, and citizens bought and owned slaves with the expectation that slaves, like any other form of property, would be secured by government. Simply nullifying a species of property without compensation was an unjust act that endangered the livelihoods (and lives) of slaveholders. But if push came to shove, it is evident from the second part of his statement that Hamilton would have favored emancipation without full compensation if full compensation were impracticable. In other words, Hamilton believed that the rights of humanity take precedence over the rights of property when the two conflict. He hoped, however, that a way could be found that would render making such a stark choice unnecessary.

\section{Putting Slavery on a Course of Ultimate Extinction}

\section{SLAvery and the Revolutionary War}

The first attempt at a compensated emancipation was conceived early in Hamilton's career by his friend John Laurens who recommended that the states of South Carolina and Georgia raise several battalions of Negro troops under the command of white officers to aid in the defense of the South during the Revolutionary War. ${ }^{33}$ The Congress would pay slaveholders up to one thousand dollars for each slave that was enlisted, and upon faithful completion of service, each Negro soldier would "be emancipated and receive the sum of fifty dollars." 34 Hamilton endorsed the plan to John Jay while Jay was president of the Continental Congress, but anticipated substantial opposition to it because of prejudice and self-interest. Prejudice came from "the contempt we have been taught to entertain for blacks," and "makes us fancy many things that are founded neither in reason

32. Ibid.

33. Hamilton, Letter to John Jay, 14 March 1779, $P A H, 2: 17-19$.

34. Library of Congress, Journals of the Continental Congress, 1774-1789, 1 Jan.22 April 1779 (Washington, D.C.: Government Printing Office, 1909), 13:387-8. 
nor experience." ${ }^{35}$ Notably, Hamilton did not share the common prejudice of Southerners concerning Negroes, which is all the more extraordinary given his upbringing on Nevis where a white plantation aristocracy likewise relied on black slaves for its way of life. He did not even "hazard" a mere "supposition" of a natural inferiority of Negroes as Jefferson did. On the contrary, Hamilton believed it was "their want of cultivation (for their natural faculties are probably as good as ours) joined to that habit of subordination which they acquire from servitude" that made Negroes inferior. ${ }^{36}$ Indeed, his more optimistic assessment of Negroes' abilities permitted him to hope that military service could contribute to the moral improvement and possible inclusion (or at least avoid a rigorous exclusion) of Negroes in American society. Giving Negroes "their freedom with their muskets," will "secure their fidelity, animate their courage, and I believe will have a good influence on those that remain, by opening a door to their emancipation." ${ }^{37}$ With successful service, Hamilton hoped that Negroes would prove to themselves and perhaps to other Americans that they, like the rest of Americans who fought in the Revolutionary War, were not simply entitled to their freedom, but worthy of it.

"True policy" also led Hamilton to endorse the plan because he predicted, "if we do not make use of them in this way, the enemy probably will." ${ }^{38}$ With the proclamations of Lord Dunmore and Sir Henry Clinton, Great Britain was able to exploit America's especially vulnerable southern flank in this way, and Hamilton singled out Virginia for being "incumbered by a numerous body of slaves bound by all the laws of injured humanity to hate their Masters." ${ }^{39}$ Modern experience quickly confirmed the lesson Hamilton had learned from Plutarch who detailed how Sparta's helots were the Achilles heel of that ancient republic. ${ }^{40}$ Hence the threat that slavery posed to the nation's security was not a matter of fleeting concern. During the Quasi-War with France, for example, Hamilton expressed his fear that France (which in 1794 banned slavery in its territories) would turn America's slaves into a fifth column: "In the South we have a vast body of blacks. We

35. Hamilton, Letter to John Jay, 14 March 1779, PAH, 2:18.

36. Ibid. (emphasis added).

37. Ibid. (emphasis added).

38. Ibid.

39. Hamilton, Eulogy on Nathanael Greene, 4 July 1789, $P A H, 5: 351$.

40. Hamilton, 1777 Pay Book, $P A H, 1: 403-404$. 
know how successful the French have been in innoculating this description of men and we ought to consider them as the probable auxiliaries of France."41

While the dictates of humanity and true policy were enough to persuade the Continental Congress to endorse Laurens's plan, they were not enough to overcome the stronger prejudice and self-interest of the lower Southern states which balked at the scheme. Nevertheless, some Northern and mid-Southern states adopted similar plans which they implemented without the involvement of the general government. ${ }^{42}$ And despite its immediate failure to gain widespread acceptance, the plan furnished the broad outlines for a general emancipation. Many Southerners like Jefferson and Madison would further insist that former slaves be removed from the country (or at least from the white population). In addition, all plans required a source of funds to defray the costs. Jefferson and Madison would favor using the proceeds from the sale of western lands. Although Hamilton never wrote anything specific on how to fund a general emancipation, he did claim that his funding system was intended to serve not only the lower ends of security and prosperity but also the higher end of enabling the federal government to undertake "liberal or enlarged plans for the public good." $43 \mathrm{He}$ also set the precedent for the federal government to provide powerful aid to the states with his plan to assume the state debts left over from the Revolutionary War. Surely if Hamilton thought it proper for the federal government to ease the burdens of the states that had provided most for the common defense, it is reasonable to suppose that once the nation's finances improved, he would have endorsed lending the federal government's support to the states for a compensated emancipation in order to establish justice and promote domestic tranquility. More-

41. Hamilton, Letter to William Loughton Smith, 10 April 1797, PAH, 21:33,39. Hamilton did not submit a plan similar to Laurens's during the Quasi-War with France presumably because of the Deep South's opposition to one during the Revolution, the Constitution's explicit protection of slavery until 1808, and especially the "probable" loyalty of slaves to France. See Letter to Charles Cotesworth Pinckey, 21 April 1800, PAH, 24:418; Letter from William C. Bentley, 19 September 1799, p.438n1. It is also notable that the New York Manumission Society helped to procure the freedom of black slaves of French immigrants from the West Indies who entered the United States after the 1794 French decree (with Hamilton sitting on a committee to establish the society's procedure for doing so). See NYMS Records, 7:172,196-200; 9:69.

42. Mary Stoughton Locke, Anti-Slavery in America: From the Introduction of African Slaves to the Prohibition of the Slave Trade (1619-1808) (Boston: Ginn and Company, 1901), pp. 82-83.

43. Alexander Hamilton, James Madison, and John Jay, The Federalist Papers, ed. Clinton Rossiter, intro. Charles R. Kesler (New York: Mentor, 1999), No. 30, p. 159. 
over, as we shall see in greater detail, Hamilton, like Jefferson and Madison, favored a gradual rather than an immediate emancipation which would make such an undertaking feasible.

\section{UNION, THE CONSTitution, AND EMANCIPATION}

Before we proceed to examine Hamilton's other efforts at extinguishing slavery, a brief survey of his views of the Constitution would be useful inasmuch as the document set limits on what could be done in the near term and eventually became the object of intense debate in the struggle over America's peculiar institution. To begin with, it should be noted that Hamilton regarded the Constitution's temporary protection of slavery as the "result of the spirit of accommodation, which governed the Convention; and without its indulgence, no union could possibly have been formed," though he pointedly added: "It will however by no means be admitted, that slaves are considered altogether as property. They are men, though degraded to the condition of slavery." 44 Hamilton's greatest fear was the violent death of the Union because there was no doubt in his mind that it was the sine qua non for the nation's security and liberties, and he warned that without the Union, America would split into mutually hostile northern and southern confederacies. ${ }^{45}$ Hamilton and other Founders therefore had to be cautious in their push to end slavery, particularly during the national government's infancy, lest they trigger a rupture that would prostrate the national government and thereby preclude any federal efforts to extinguish slavery. ${ }^{46}$ At the same time, the Constitution's concessions to slavery were not intended to be permanent as evidenced by the expiration in 1808 of the restriction on banning the importation of slaves. Indeed, there are more than adequate grounds to assert that Hamilton's interpretation of the Constitution, perhaps more than any other Founder's, supplied the federal government with the requisite powers to confine and eventually extinguish slavery.

In general terms, Hamilton himself originated the doctrine of a "liberal construction" of the powers of the federal government. ${ }^{47}$

44. Hamilton, Remarks in the N.Y. Ratifying Convention, 20 June $1788, P A H$, 5:24. During the Constitutional Convention, Hamilton proposed that representation in the national legislature be based solely on the number of free inhabitants. Max Farrand, ed., The Records of the Federal Convention of 1787 (New Haven: Yale University Press, 1966), 1:36.

45. The Federalist Papers, Nos. 6-8, 11, pp. 21-39, 59.

46. See also Donald L. Robinson, Slavery in the Structure of American Politics, 1765-1820 (New York: Harcourt, Brace, Jovanovich, Inc., 1971), p. 425.

47. Hamilton, "Opinion On the Constitutionality of an Act to Establish a National Bank," PAH, 8:105. 
More specifically, if the decision of (fellow Federalist) Chief Justice John Marshall in Gibbons v. Ogden (1824), giving the federal government wide latitude to regulate interstate commerce, was any indication of Hamilton's own views, the federal government undoubtedly had the power to "interfere" with the slave trade between the states and possibly even within the states. ${ }^{48}$ As for the territories, Article 4, section 3, of the Constitution specifically addresses the matter: "The Congress shall have Power to dispose of and make all needful Rules and Regulations respecting the Territory or other Property belonging to the United States." The only problem is interpreting the word "needful." Hamilton, of course, dilated extensively on the meaning of a synonymous word, necessary, which he argued "often means no more than needful, requisite, incidental, useful, or conducive to." 49 In Hamilton's view, the word necessary was not intended as a restrictive adjective, and so Congress would be well within its prerogatives to ban slavery in the territories. Madison, by contrast, construed the term narrowly and therefore did not consider "the interdict of slavery among the needful regulations contemplated by the constitution." 50 Raising revenue for a plan of compensated emancipation would likewise pass constitutional muster given Hamilton's opinion that so long as the federal government did not spend money for a purpose which is "merely or purely local," then "there can be no want of constitutional power." 1 As for the related issue of states' rights, Hamilton foretold "the tendency of the doctrines advanced by Virginia and Kentucky to destroy the Constitution of the United States," and set the precedent for using force to defend the Constitution when he called out federal troops to quell the Whiskey Rebellion. ${ }^{52}$ In sum, Hamilton's interpretation of the Constitution armed the federal government with ample power to put slavery on a path to extinction, even at the point of the bayonet if necessary.

48. Gibbons v. Ogden, 9 Wheat 1, 6 L. Ed. 23 (1824). An inlet for the federal government to interfere with slavery within the states comes from Marshall's reservation to the states only such commerce that is "completely internal" to a state. Since the products of slave labor did cross state lines, they, and therefore slavery, might be eligible for regulation by the federal government. Compare Wickard v. Filburn (1942).

49. Hamilton, "Opinion On the Constitutionality of an Act to Establish a National Bank," PAH, 8:102-103, 98.

50. James Madison, Letter to Robert Walsh, 27 November 1819, in James Madison: Writings (New York: The Library of America, 1999), p. 740.

51. Hamilton, "Opinion On the Constitutionality of an Act to Establish a National Bank," PAH, 8:129.

52. Hamilton, Letter to Theodore Sedgwick, 2 February 1799, PAH, 22:452. 
Before it came to that, however, Hamilton hoped that gentler methods could be employed for the gradual abolition of slavery. First, there was his conduct of American foreign policy which displayed a clear sympathy for slaves. Second, there were his efforts to bring about a gradual emancipation through the state abolition societies. Finally, there was his program to make America a commercial rather than an agrarian society which would both undermine slavery and provide the best viable economic alternative to it.

\section{SlaVery, HaIti, and the Jay TREATY}

Two issues of foreign policy illustrate Hamilton's efforts to ease the plight of slaves. The first concerned America's response to a series of slave revolts that began in 1791 on the island of Saint Domingue, or Haiti, eventually led by Francois Dominique Toussaint. ${ }^{53}$ Hamilton initially favored a policy "restricted to the single idea of preserving the colony from destruction by famine" because it was unclear which government, French or slave, warranted recognition, but when Toussaint finally managed to become the strongest force on the island in 1798, Hamilton tilted in favor of Toussaint. ${ }^{54}$ After Congress passed a law which authorized opening relations with Toussaint's government in 1799, Hamilton instructed Timothy Pickering, secretary of state under President Adams, to give Toussaint verbal assurances that "upon his declaration of independence a commercial intercourse will be opened, and continue while he maintains it, and gives due protection to our vessels and property." Although Hamilton believed that the United States should not commit itself to Haiti's independence, he was inclined "to think the declaration of independence ought to proceed." 55 Certainly, geopolitical considerations influenced his position, but it does show that Hamilton (unlike Jefferson) was perfectly willing to embrace a nation of free blacks in close proximity to the United States. ${ }^{56}$

53. Finkelman, Slavery and the Founders, p. 121; Robinson, Slavery in the Structure of American Politics, pp. 347-77.

54. Hamilton, Letter to George Washington, 19 Nov. 1792, PAH, 13:171. The French government was likewise unstable. Robert A. Hendrickson, The Rise and Fall of Alexander Hamilton (New York: Van Nostrand Reinhold Co., 1981), pp. 504505.

55. Hamilton, Letters to Timothy Pickering, $9 \& 21$ February $1799, P A H$, $22: 475,492-93$. Historians frequently fail to mention that Pickering received his instructions in this matter (as in most matters) from Hamilton.

56. Finkelman, Slavery and the Founders, pp. 121-23. 
The issue of slavery once again reared its head in the debate over ratification of the Jay Treaty. Following the end of the Revolutionary War, Britain carried away a number of American slaves and later manumitted them in apparent violation of the treaty of peace. This infuriated Southern slaveholders especially because many of them were groaning under the weight of debts owed to British citizens (although Southerners felt no compunction in seizing and selling Tory estates and slaves). ${ }^{57}$ Many Southerners (including Jefferson and Madison) wanted to stipulate in any subsequent treaty with Britain that those slaves be returned. The Jay Treaty, however, remained silent on the issue which meant that the United States was unlikely ever to press any claims on the matter.

In contrast to Southerners, Hamilton, while admitting Britain's nefarious tactics, asserted that "Truth and Justice" were on Britain's side because the laws of nations contain a certain hierarchy. Although property captured in war ought to be restored as stipulated in a treaty, slaves were not mere property but human beings endowed with unalienable rights. Since the rights of humanity are higher than the rights of property, returning the freed slaves would have been wrong: "If once declared free, could the grant be recalled? Could the British Government stipulate the surrender of men made free to slavery? Is it natural to put such a construction upon general words if they will bear another? Is not this as it regards the rights of humanity an odious sense?" 58 This does not mean, however, that Hamilton believed that freeing slaves without compensating their owners should be a general practice. The issue confronting him was: given that the slaves had already been freed, which would be the greater evil-returning the slaves or failing to compensate their owners? Hamilton believed that returning the slaves was the greater evil and had the courage and magnanimity to defend his position despite the harm it caused to domestic American interests. In other words, Hamilton sanctioned a breach of faith to American slaveholders not in the name of low necessity, but in the name of a higher moral obligation.

\section{The State Abolition Societies}

After the Revolutionary War, more significant efforts to end slavery occurred in the states (which were free to legislate on the matter as they saw fit) with the formation of abolition or manumission societ-

57. Samuel F. Bemis, Jay's Treaty (New York: Macmillan, 1923), pp. 96-102; Jerald A. Combs, The Jay Treaty (Los Angeles: University of California Press, 1970), p. 83; Mary Stoughton Locke, Anti-Slavery in America, p. 84.

58. Hamilton, "Remarks on the Treaty of Amity Commerce and Navigation lately made between the United States and Great Britain," $P A H, 18: 417$; "The Defence," No. III, PAH, 18:513-23. 
ies. ${ }^{59}$ Hamilton's home state of New York seemed in particular in need of such a society since it possessed more slaves than the combined total of the states north of the Mason-Dixon Line. ${ }^{60}$ Accordingly, the New York Society for Promoting the Manumission of Slaves was organized in 1785 with Hamilton in attendance. ${ }^{61}$ John Jay was elected its first president, and Hamilton was appointed chairman of a committee charged with making recommendations for the society's code of conduct. Hamilton's committee proposed that members undertake a gradual emancipation which would free their oldest slaves immediately and their youngest ones by the age of $35 .^{62}$ The proposal failed to muster enough support to pass and ultimately died (although in 1809 the society denied membership to anyone owning slaves). ${ }^{63}$ As was his wont, Hamilton was pushing too hard too fast. Whether Hamilton himself owned slaves is not entirely clear, but Forrest McDonald makes a solid case that he did not. ${ }^{64}$ In any event, his proposal would serve as the basis for the policy of gradual emancipation that the society would urge for the state as a whole. Gradual emancipation would also dramatically cut the costs of emancipation because it entailed freeing not adult slaves, but the children of slaves born after a certain future time. The children, in turn, would be bound to their masters essentially as indentured servants until they reached adulthood (most commonly the age of 21 or 28 ) which would more than cover the costs of rearing them. And since infants (who had to be reared and frequently died before adulthood) were worth less than a tenth of an adult slave (Jefferson valued an infant at $\$ 12.50$ compared to the adult price of $\$ 200$ ), the costs of compensating slaveholders would be manageable. ${ }^{65}$

Hamilton remained an active member in the society during his life, becoming its second president and serving on various commit-

59. Mary Stoughton Locke, Anti-Slavery in America, pp. 97-98.

60. Census figures for 1790 show New York with 21,193 slaves, or 6 percent of its population. While certainly not on the scale of the South, New York's relatively large slave population undermines the view that slavery would inevitably be extinguished there. Inter-University Consortium for Political and Social Research, Study 00003: Historical Demographic, Economic, and Social Data: U.S., 1790-1970 (Ann Arbor: ICPSR), http://fisher.lib.virginia.edu/cgi-local/censusbin/census/cen.pl.

61. "Attendance at a Meeting of the Society for Promoting the Manumission of Slaves," 4 February 1785, $P A H, 3: 597$. For a history of the society, see Thomas R. Moseley, "A History of the New-York Manumission Society, 1785-1849" (Ph.D. diss., Nwy York University, 1963).

62. NYMS Records, 6:29-31.

63. Ibid., 6:61.

64. McDonald, Alexander Hamilton, p. 373n12.

65. Robert William Fogel and Stanley L. Engerman, Time on the Cross (Boston: Little, Brown, and Co., 1974), pp. 35-36; James Curtis Ballagh, A History of Slavery in Virginia (Baltimore: The Johns Hopkins Press, 1902), pp. 130-31. 
tees. He also became one of the first counsellors-at-law and served in that post from 1798 until his death. ${ }^{66}$ The four counsellors were responsible for suggesting changes in state laws regarding slavery and suing on behalf of free blacks who were illegally kept in bondage or captured and sold. ${ }^{67}$ In fact, most of the society's routine operation consisted of efforts to ensure that laws regarding the freedom of blacks were vigorously enforced (which of course is the hallmark of Hamiltonian administration).

The society was no less vigorous in pressing the state legislature for a gradual emancipation. Within two months of its founding, the society circulated a petition for that purpose before it was sent on to the legislature. ${ }^{68}$ The following year, Hamilton was appointed to a committee which drafted a petition urging an end to the slave trade, "a commerce so repugnant to humanity, and so inconsistent with the liberality and justice which should distinguish a free and enlightened people." ${ }^{99}$ Although it proved impossible to extinguish slavery in one stroke, the society was content to pursue a strategy of incremental change that soon began bearing fruit. In 1785, the New York legislature passed a liberal manumission act that allowed slaveholders to free a slave without security before the slave reached the age of fifty. ${ }^{70}$ In the same year, the legislature also passed a law which prohibited the sale of slaves brought into the state. In 1788 , the legislature passed a law that made it illegal to purchase or to receive slaves with the intent to sell them in another state. ${ }^{71}$ The latter two acts paved the way for gradual emancipation by stanching the flow of slaves into and out of the state. With Jay's election to governor in 1796 , the society petitioned the New York legislature once again to pass an emancipation act. ${ }^{72}$ Although several bills to that end were narrowly defeated over the thorny issue of compensation, a gradual emancipation act was finally passed in 1799 (followed by a definitive emancipation in 1817) ${ }^{73}$ Beginning on 4 July 1799, the act freed all children born to slaves within the

66. NYMS Records, 6:124,142; 9:4,7,30,53,75,95,113.

67. Ibid., 6:121.

68. Ibid., 6:17,19.

69. Ibid., 6:37,44; "Memorial to Abolish the Slave Trade," 13 March 1786, PAH, 3:654.

70. Mary Stoughton Locke, Anti-Slavery in America, p. 121-22. Manumission acts did not free slaves, but eased the restrictions and requirements for manumission. The most onerous of these was requiring a slaveholder to post a bond before manumitting a slave in order to prevent the freed slave from becoming a public charge.

71. NYMS Records, 6:94-95.

72. Ibid., 6:240.

73. Mary Stoughton Locke, Anti-Slavery in America, 123-24, 128; Frank Monaghan, John Jay: Defender of Liberty (New York: The Bobbs-Merrill Co., 1935), p. 422. 
state, but they were to work for the master of their household until the age of 28 if male, 25 if female. The act omitted any direct compensation to slaveholders which was in effect an endorsement of Hamilton's position that the "impracticability" of full compensation "ought not to be an obstacle to a clearly essential reform."

Although securing the freedom of slaves was its most important aim, the society was equally determined to help prevent free blacks from languishing in a state of ignorance, dissipation, and poverty. Thus in 1787 the society opened the doors of the African Free School in New York City to educate black children. ${ }^{74}$ The school would also allow the society to demonstrate to skeptical whites that blacks are "not inferior to those of fairer complexions, either in acquiring a knowledge of Letters or in a pleasing or orderly behaviour" in much the same way that Hamilton hoped the establishment of a good national government would "vindicate the honor of the human race" against the "arrogant pretensions of the European" who likewise claimed a "physical superiority." held annual public exhibitions, and newspaper coverage of them soon followed. ${ }^{76}$ And given the initial public prejudice against the school, it probably would not have had much success without the imprimatur of such distinguished figures as Hamilton, Jay, James Duane, Melancton Smith, Robert Troup, Noah Webster, et al. ${ }^{77}$ Their influence also allowed the society to obtain funds for the school from private individuals, the city of New York, and the state legislature. ${ }^{78}$

It was not long before the society became active in national politics as well. The society's first effort-a memorial to the Constitutional Convention urging a gradual emancipation - was aborted when the society learned that the Convention was unlikely to take up the subject. ${ }^{79}$ In 1790, the New York Manumission Society suggested that the various state abolition societies meet at annual conventions to coordinate their efforts and unite in an address to Congress after their separate petitions to Congress asking for limits on the slave trade fell on deaf ears. ${ }^{80}$ In addition to memorials to Congress and to

74. NYMS Records, 6:80-91. See also Charles C. Andrews, The History of the New York African Free-Schools (New York: Mahlon Day, 1830; reprint, New York: Negro Universities Press, 1969).

75. NYMS Records, 6:123; The Federalist Papers, No. 11, pp. 58-59.

76. Andrews, The History of the New York African Free-Schools, pp. 34-35, 38-39, 44-49.

77. NYMS Records, 6:8-13.

78. Ibid., 6:239,264; 9:13,39,65,80-81.

79. Ibid., 6:72-74.

80. Mary Stoughton Locke, Anti-Slavery in America, p. 101. 
the state legislatures, the conventions also prepared addresses to the citizens of the United States at large. While it is uncertain whether Hamilton had a direct hand in composing these addresses, it is certain that the abolition societies objected to leaving the slavery and antislavery interests to be checked and channeled within the machine of government because slavery was not a matter of mere interest that the people could vote up or down depending on whether they found it profitable. Rather, the slave interest was a "faction" as Publius defined the term - an interest derived from the passion of avarice opposed both to the rights of individuals and to the common goodand the slave faction was particularly insidious and virulent such that it could not be contained, much less overcome, solely by the "auxiliary precautions" of the improved science of politics. ${ }^{81}$ The slave faction could ultimately only be overcome by direct efforts at molding public opinion, or to use the language of Federalist, No. 10, by giving citizens "the same opinions, the same passions, and the same interests" ${ }^{82}$ with respect to slavery. Americans would have to be inculcated with the belief "that the benevolent Author of nature has made no effectual distinction in the human race, and that all the individuals of the great family of mankind have a common claim upon the general fund of natural bounties," and furthermore, that is was their duty to "lay the foundation for an eventual extinction of the mighty evil throughout our land." ${ }^{83}$

\section{SlaVery AND COMmERCE}

While understanding the necessity of inculcating in citizens an opinion that slavery was wrong, Hamilton also understood the necessity of establishing an institutional framework that would both reinforce that opinion and provide a viable economic substitute to slavery. Not surprisingly, he turned to commerce to do just that. Hamilton believed that commerce in general has its own ethos which is essentially incompatible with slavery and as such tends to undermine it, but he also believed that America would have to pursue a thoroughly industrial commerce if it was to put an end to slavery once and for all. ${ }^{84}$

81. The Federalist Papers, No. 51, p. 290; No. 9, p. 40.

82. Ibid., No. 10 , p. 46.

83. "Minutes of the Proceedings of the Seventh Convention of Delegates from the Abolition Societies Established in different parts of the United States, Assembled at Philadelphia on the Third of June, One Thousand Eight Hundred and One" (Philadelphia: Zachariah Poulson, Jr., 1801), pp. 37, 41.

84. There has been a vigorous academic debate over whether commerce by itself would have put an end to slavery. For an excellent bibliographic essay on the subject, see Jeffrey Rogers Hummel, Emancipating Slaves, Enslaving Free Men: A History of the America Civil War (Chicago: Open Court, 1996), pp. 61-75. 
The ethos which Hamilton saw as the main culprit in producing slavery is what Hegel would later call the master or warrior ethic, epitomized in the ancient republics of Sparta and Rome. Sparta, of course, was renowned for its helots and imperialism. ${ }^{85}$ The history of Rome likewise "proves that War and Conquest were the great business of that People." ${ }^{16}$ In delving into ancient Roman law, Hamilton learned from Cicero that the Romans derived the "right of capturing the property and of making slaves of the persons of enemies" from "the right of killing them, which was regarded as absolute and unqualified extending even to Women and Children." 87 This "horrible" and "detestable" doctrine also served to justify enslaving all whom the Romans regarded as enemies. ${ }^{88}$ As a result, Rome's dependent provinces "were made the continual scene of rapine and cruelty." 89

In fact, Hamilton believed that the practice of slavery is itself nothing more than war carried from the battlefield to the household. The slaveholder "riots in the spoils" of the labor of his slave, and "despises the hand by which he is fed." Slavery inflames the ambition, avarice, and lusts of the master as his every whim is tended to while demeaning and dehumanizing the slave. ${ }^{90}$ In short, slavery in a regime is "fatal to religion and morality" and "tends to debase the mind, and corrupt its noblest springs of action." 1

In Montesquieu's analysis of the ancient republics, slavery was necessary to provide for men who devoted themselves to military and political glory, and to a lesser extent, leisured pursuits like the liberal arts. As an activity grounded in man's necessities rather than his freedom, toiling for one's bread was regarded with contempt. Therefore "one did not want the citizens to work in commerce, agriculture or the [mechanical] arts." Indeed, the ancient cities so despised labor and commerce that David Hume was unable to find "a passage in any ancient author, where the growth of a city is ascribed to the establishment of a manufacture." 93

85. Hamilton, "1777 Pay Book," $P A H, 1: 403$.

86. Hamilton, "The Defence No. XX," $P A H, 19: 332$.

87. Ibid., pp. 332-33.

88. Ibid., 333.

89. Hamilton, "A Full Vindication," $P A H, 1: 53$.

90. Ibid.

91. Ibid.

92. Montesquieu, The Spirit of the Laws, trans. Anne M. Cohler, Basia C. Miller, and Harold S. Stone (New York: Cambridge University Press, 1989), part 1, bk. 4, chap. 8, pp. $40-41$.

93. David Hume, "Of the Populousness of Ancient Nations," in Essays: Moral, Political, and Literary, ed. Eugene F. Miller (Indianapolis: Liberty Classics, 1987), p. 418. 
Yet, according to Montesquieu, it was precisely the relative lack of commerce that was largely responsible for the spirit of rapine that pervaded the ancient republics. Montesquieu famously argued that "everywhere there is commerce, there are gentle mores." While admitting that "commerce corrupts pure mores," it "polishes and softens barbarous mores." 94 Hamilton confirmed Montesquieu's basic analysis in Federalist, No. 8:

The industrious habits of the people of the present day, absorbed in the pursuits of gain and devoted to the improvements of agriculture and commerce, are incompatible with the condition of a nation of soldiers, which was the true condition of those [ancient] republics. ${ }^{95}$

Hamilton also agreed that commerce has a "softening and humanizing influence" on the mores of men. ${ }^{96}$ Nevertheless, he was far less sanguine than Montesquieu about commerce's ability to tame the warlike spirit of man as evidenced by his arguments in Federalist, No. 6, that the spread of commerce would not put an end to wars among nations. ${ }^{97}$ Hence it is more accurate to say that Hamilton believed that commerce had a moderate tendency to restrain the spirit of the master, and to that extent the practice of slavery.

In addition to humanizing people's mores, commerce would also humanize people's opinions by virtue of its tendency to promote the cultivation of the arts. Hamilton saw the "improvement of moral science in modern times" as being responsible for rejecting "altogether the right of imposing slavery on captives. $"{ }^{8}$ Commerce would assist in the diffusion of such improvements in moral knowledge as it eases communication and assimilates manners. ${ }^{99}$

As useful as it would be in humanizing people's mores and opinions, commerce would be more useful in supplying a viable economic alternative to slavery. But not just any form of commerce. It would have to be industrial commerce because the agrarian commerce that Drew McCoy sees as the heart of the political economy of Jefferson and Madison (and the Democratic-Republicans generally) would only make it that much more difficult to eliminate

94. Montesquieu, The Spirit of the Laws, part 4, bk. 20, chap. 1, p. 338.

95. The Federalist Papers, No. 8, p. 37.

96. Hamilton, "The Defence No. XX," $P A H, 19: 332$.

97. The Federalist Papers, No. 6, pp. 21-28. See also Karl-Friedrich Walling, Republican Empire: Alexander Hamilton on War and Free Government (Lawrence, KS: University Press of Kansas, 1999), pp. 176-85.

98. Hamilton, "The Defence No. XX," PAH, 19:333.

99. Montesquieu, The Spirit of the Laws, part 4, bk. 20, chaps. 4-5, p. 357. The Federalist Papers, No. 60, p. 335. 
slavery since the demand for slaves came overwhelmingly from (plantation) farmers. ${ }^{100}$ Prolonging the "agricultural stage" in America via westward expansion meant in effect prolonging the curse of slavery. By contrast, Hamilton considered it unwise to provide "any extraordinary impulse to a transfer of people from the settled to the unsettled parts of the country" in part because it would "retard the progress of general improvement."101 Progress required cities and manufacturers, not more villages and farmers. And the progress of manufactures - which Hamilton endeavored to accelerate by direct government patronage - would aid in ending the curse of slavery by diversifying the economy and promoting technological innovation.

The most obvious effect of diversifying an economy of mere cultivators into an economy of "cultivators, artificers and merchants," 102 is to reduce the agricultural share of the economy. In fact, Hamilton expected that his program to encourage manufactures would help "to detach a portion of the hands which would otherwise be engaged in tillage" and "cause a smaller quantity of lands to be under cultivation." 103 This, in turn, would decrease the demand for slaves and at the same dilute the influence of the agricultural interest bent on retaining slavery. Admittedly, Hamilton never directly made this claim-he would instead stress the benefits to agriculture from manufacturingbut he was probably aware that his argument for diversifying the economy pointed in this direction, especially when considered in light of Federalist, No.10. ${ }^{104}$

Yet if all slaves were to freed, a substitute for them was necessary, which Hamilton found in the technology or machines that industrial commerce produces. As Montesquieu observed, "With the convenience of machines invented or applied by art, one can

100. Drew R. McCoy, The Elusive Republic: Political Economy In Jeffersonian America (Chapel Hill, NC: The University of North Carolina Press, 1980), chaps. 5, 8; Roger G. Kennedy, Mr. Jefferson's Lost Cause: Land, Farmers, Slavery, and the Louisiana Purchase (New York: Oxford University Press, 2003), pp. 12-16, 78-81.

101. Hamilton, "The Defence of the Funding System," $P A H, 19: 40$.

102. Hamilton, "Report on the Subject of Manufactures," $P A H, 10: 256$.

103. Ibid., p. 259.

104. Hiram Caton makes a similar point: "The Report [on Manufactures] had two further political implications that Hamilton did not stress. ... Hamilton might reasonably hope that the growth of manufactures would in the long run dilute the influence of the rural interests and the dangerous localisms of husbandmen" (The Politics of Progress: The Origins and Development of the Commercial Republic, 1600-1835 [Gainesville, FL: University of Florida Press, 1988], p. 477). 
replace the forced labor that elsewhere is done by slaves." $105 \mathrm{Be}-$ sides reading Montesquieu, Hamilton recorded in his pay book the following passage from Plutarch which suggests a link between slavery and the absence of the mechanical arts (or technology): "The Spartans despised all labour and mechanic arts; arms were the only honorable profession." ${ }^{106}$ In his Report on Manufactures, Hamilton noted "the vast extension given by late improvements to the employment of machines-which, substituting the agency of fire and water, has prodigiously lessened the necessity for manual labor." ${ }^{07}$ Clearly, Hamilton saw the connection between slavery and the mechanical arts, and it could not have escaped his understanding that the promotion of the mechanical arts would be a powerful means by which the "necessity for manual labor" done by slaves might be eliminated. But how best to promote technological innovation? Certainly not with slavery since it "relaxes the sinews of industry, [and] clips the wings of commerce." 108 After all, if there is any form of labor that lacks "adequate motives to excite a spirit of discovery and contrivance," it is slave labor since slaves would reap little, if any, reward for their discoveries. ${ }^{109}$ Among free economic activities, Hamilton found that "manufacturing pursuits are susceptible, in a greater degree, of the application of machinery, than those of agriculture." 110 In fact, it is because of manufacturing (and not agriculture) that "the fabrication of Machines, in numerous instances" has become "itself a distinct trade." 111 Hence the greatest hope for producing the kind of technological innovation that would make possible the substitution of machines for slaves did not lie in an agrarian commercial republic but in a fully industrialized nation.

105. Montesquieu, The Spirit of the Laws, part 3, bk. 13, chap. 8, p. 252.

106. Hamilton, "1777 Pay Book," $P A H, 1: 402$ (emphasis added).

107. Hamilton, "Report on Manufacturers," $P A H, 10: 270$.

108. Hamilton, "A Full Vindication," $P A H, 1: 53$. "Sorry I am to say that mine is still backward in the encouragement of manufactorys or artists, but I trust it will soon get better as the Slavery by blacks decreases \& by Emigration from these Countrys we get betterd as to a free tenantry." Thomas Digges to Hamilton, 6 April 1792, $P A H, 11: 242$.

109. Hamilton, "Second Draft of the Report on Manufactures," $P A H, 10: 54$. The passage quoted refers to farmers rather than slaves, but it applies to slaves with even more force. See also Adam Smith, An Inquiry Into the Nature and Causes of the Wealth of Nations, ed. Edwin Cannan (New York: The Modern Library, 1937), bk. 4, chap. 9, p. 648.

109. Hamilton, "Report on Manufactures," PAH, 10:251-52.

110. Ibid.

111. Ibid. 


\section{Conclusion}

As it happened, industrial commerce did ultimately provide the means for abolishing slavery. Great Britain, the leader in industrial commerce, along with France, which was not far behind, were the first major European nations to abolish slavery outright. And without industrialization, it would be difficult to see how slavery might be abolished. Unfortunately for America, industry would produce an innovation that would give a new lease on slavery in the South: the cotton gin. As the production of cotton was particularly suited to the use of slaves, the sharp reduction in the cost of producing cotton, made possible by the cotton gin, substantially increased the demand for (and ultimately the trade in) slaves. This proved that while industrial commerce was perhaps the necessary condition for eliminating slavery, it was hardly the sufficient condition, something Hamilton fully realized, for otherwise there would have been no point to his other efforts on behalf of emancipation. What Hamilton would have done had he lived long enough to see the cancer of slavery grow and spread is unclear. What is clear is that it would require the greatest efforts of the greatest of statesmen-perhaps even greater than that of Hamilton-to make America atone for its original sin, and give America "a new birth of freedom." 